\title{
Metabolic Syndrome: Comparison of Occurrence Using Three Definitions in Hypertensive Patients
}

\author{
Adeseye A. Akintunde, MBChB, FWACP; Olugbenga E. Ayodele, MBBS, FWACP; \\ Patience O. Akinwusi, MBChB, FWACP; and George O. Opadijo, MBBS, FWACP
}

\begin{abstract}
Objective: To compare the frequency of occurrence of metabolic syndrome using three international definitions and to study the distribution of cardiovascular risk factors among newly diagnosed hypertensive Nigerian subjects.
\end{abstract}

Design: Cross sectional study.

Settings: Cardiology unit of LAUTECH Teaching Hospital, Osogbo, Nigeria.

Participants: One hundred forty newly diagnosed hypertensive Nigerian subjects, and 70 normotensive controls (age- and sex-matched) were included in this study.

Methods: Clinical history and relevant laboratory investigations were performed on all study participants. The definition of metabolic syndrome was based on three international definitions:World Health Organization (WHO), International Diabetes Federation (IDF), and National Cholesterol Education Program Adult Treatment Panel III (NCEP ATP III). Ethical approval was obtained for the study. Statistical analyses were performed using SPSS 16.0.

Results: There was no difference in age and gender distribution between the hypertensive subjects and controls. $(55.14 \pm 10.83$ years, females $53.6 \%$ vs. $54.67 \pm 10.89$ years, females $52.9 \%$ respectively, $P>0.05)$. The frequency of occurrence of metabolic syndrome among hypertensives was $34.5 \%$ according to WHO, $35.0 \%$ according to NCEP ATP III, and $42.5 \%$ according to IDF criteria. Visceral obesity and reduced high-density lipoprotein (HDL) were the other common cardiovascular risk factors among newly diagnosed hypertensive subjects. Female hypertensives had a higher prevalence of visceral obesity and low HDL.

Conclusion: Frequency of occurrence of metabolic syndrome was similar using the NCEP ATP III and WHO definitions. However, the IDF definition resulted in a higher frequency because of the lower cut-off for waist circumference used for identification of visceral obesity. Metabolic syndrome is present in a significant proportion of newly diagnosed hypertensive subjects. Therefore, appropriate screening and treatment are required.

Keywords: Frequency of occurrence; Hypertension; Metabolic syndrome; Obesity

Corresponding Author: Adeseye A. Akintunde, MBChB, FWACP; Division of Cardiology; University Hospital; 72074 Otfried Müller Street 10; Tubingen, Germany; Tel: +49-15227790/46; Fax: +234-803-393-2076; Email: iakintunde2@yahoo.com
Received: November 30, 2009

$I^{\text {st }}$ Revision: January 30, 2010

$2^{\text {nd }}$ Revision: May 19, 2010

Accepted: May 25, 2010 
$\mathrm{M}$ constellation of cardiovascular disease risk factors. The risk factors include elevated blood pressure, dyslipidemia (hypertriglyceridemia, low levels of high density lipoprotein [HDL] cholesterol), hyperglycemia, and central obesity. ${ }^{1,2}$ Hypertension is a common cardiovascular disease risk factor worldwide. ${ }^{3,4,5}$ Hypertension frequently coexists with many other cardiovascular disease risk factors such as obesity, dyslipidemia, impaired glucose tolerance (or hyperglycemia), and hyperuricemia. ${ }^{6-10}$

There are many definitions of metabolic syndrome, as recommended by the various working groups. ${ }^{11-13}$ However, the core components of the syndrome which include increased waist circumference, impaired glucose tolerance, dyslipidemia, and hypertension, are commonly required by all the various groups for diagnosis. ${ }^{1,11-13}$ Prevalence of metabolic syndrome varies in different populations and is influenced by several factors including age, race, gender, socio-economic status, work-related activities, and cultural views on body fat. ${ }^{14}$ Although the various definitions measure similar components, each uses different combinations of cardiovascular disease risk factors. The World Health Organization (WHO) in 1999 made insulin resistance evaluated by the euglycemic study as the pivot for the diagnosis of metabolic syndrome. ${ }^{11,14}$ The National Cholesterol and Education Program Adult Treatment Panel III (NCEP ATP III), International Diabetes Federation (IDF), and American Association of Clinical Endocrinology (AACE) adopted visceral obesity as the pivot for the diagnosis of metabolic syndrome. However, the European Group for the Study of Insulin Resistance (EGIR) suggested that the underlying etiology in the clustering of cardiovascular risk factors is insulin resistance. ${ }^{11-14}$ The WHO, NCEP ATP III, and IDF criteria for diagnosis of metabolic syndrome are outlined in table 1 .

Metabolic syndrome has been associated with an increased tendency to develop type 2 diabetes mellitus and cardiovascular diseases. ${ }^{15-17}$ The various criteria identify similar sets of people with cardiovascular risk factor clustering. The IDF definition includes a race-specific cut-off for visceral obesity. Abdominal obesity is race- and gender-specific as suggested by many population studies. ${ }^{1,10}$ Information on the frequency of occurrence of metabolic syndrome in newly diagnosed hypertensive Black African patients is scarce. A comparative analysis of three standard international definitions for diagnosing metabolic syndrome is expected to give an

Table 1. Definition of metabolic syndrome based on different criteria used.

\begin{tabular}{|c|c|c|c|}
\hline Clinical Measure & WHO (1999) ${ }^{11}$ & ATP III (2001) ${ }^{12}$ & IDF $(2005)^{13}$ \\
\hline Insulin resistance & $\begin{array}{l}\text { IGT, IFG, T2DM, or lowered } \\
\text { insulin sensitivity, } \\
\text { plus any } 2 \text { of the below } \\
\text { listed features }\end{array}$ & $\begin{array}{l}\text { None, but any } 3 \text { of the } 5 \\
\text { features listed below }\end{array}$ & None \\
\hline Body weight & $\begin{array}{l}\text { Men: WHR }>0.90 \\
\text { Women: WHR }>0.85 \\
\text { and/or } \mathrm{BMI}>30 \mathrm{~kg} / \mathrm{m}^{2}\end{array}$ & $\begin{array}{l}W C \geq 102 \mathrm{~cm} \text { in men } \\
W C \geq 88 \mathrm{~cm} \text { in women }\end{array}$ & $\begin{array}{l}\text { Increased WC (population } \\
\text { specific) plus any } 2 \text { of the } \\
\text { features listed below }\end{array}$ \\
\hline Lipid & $\begin{array}{l}\mathrm{TG} \geq 150 \mathrm{mg} / \mathrm{dL}(1.7 \\
\mathrm{mmol} / \mathrm{L}) \text { and/or } \\
\mathrm{HDL}-\mathrm{C}<35 \mathrm{mg} / \mathrm{dL} \\
(0.9 \mathrm{mmol} / \mathrm{L}) \text { in men } \\
\mathrm{HDL}-\mathrm{C}<39 \mathrm{mg} / \mathrm{dL} \\
(1.0 \mathrm{mmol} / \mathrm{L}) \text { in women }\end{array}$ & $\begin{array}{l}\mathrm{TG} \geq 150 \mathrm{mg} / \mathrm{dL} \\
(1.7 \mathrm{mmol} / \mathrm{L}) \\
\mathrm{HDL}-\mathrm{C}<40 \mathrm{mg} / \mathrm{dL} \\
(1.03 \mathrm{mmol} / \mathrm{L}) \mathrm{in} \mathrm{men} \\
\mathrm{HDL}-\mathrm{C}<50 \mathrm{mg} / \mathrm{dL} \\
(1.29 \mathrm{mmol} / \mathrm{L}) \text { in women }\end{array}$ & $\begin{array}{l}\mathrm{TG} \geq 150 \mathrm{mg} / \mathrm{dL}(1.7 \mathrm{mmol} / \mathrm{L}) \text { or } \\
\text { on } \mathrm{TG} \text { treatment } \\
\mathrm{HDL}-\mathrm{C}<40 \mathrm{mg} / \mathrm{dL} \\
(1.03 \mathrm{mmol} / \mathrm{L}) \text { in men } \\
\mathrm{HDL}-\mathrm{C}<50 \mathrm{mg} / \mathrm{dL} \\
(1.30 \mathrm{mmol} / \mathrm{L}) \text { in women or } \\
\text { on } \mathrm{HDL}-\mathrm{C} \text { treatment }\end{array}$ \\
\hline Blood pressure & $\geq 140 / 90 \mathrm{mmHg}$ & $\geq 130 / 85 \mathrm{mmHg}$ & $\begin{array}{l}\geq 130 \mathrm{mmHg} \text { systolic or } \\
\geq 85 \mathrm{mmHg} \text { diastolic or } \\
\text { on hypertension treatment }\end{array}$ \\
\hline Glucose & IGT, IFG, or T2DM & $\begin{array}{l}>110 \mathrm{mg} / \mathrm{dL}(6.1 \mathrm{mmol} / \mathrm{L}) \\
\text { (includes diabetes) }\end{array}$ & $\begin{array}{l}\geq 100 \mathrm{mg} / \mathrm{dL}(5.6 \mathrm{mmol} / \mathrm{L}) \\
\text { (includes diabetes) }\end{array}$ \\
\hline Others & $\begin{array}{l}\text { Microalbuminuria: } \\
\text { UAE }>20 \mu \mathrm{g} / \mathrm{min} \text { or } \\
\text { urinary } \mathrm{ACR}>30 \mathrm{mg} / \mathrm{g}\end{array}$ & & \\
\hline
\end{tabular}

WHO=World Health Organization; ATP III= Adult Treatment Panel III; IDF= International Diabetes Federation; IGT=impaired glucose tolerance; impaired fasting glycemia; T2DM=Type 2 diabetes mellitus; WHR=waist-hip ratio; $B M I=$ body mass index; WC=waist circumference; TG=triglycerides; HDL-C=high-density lipoprotein

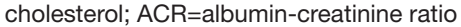


Table 2. Clinical and demographic parameters of study participants.

\begin{tabular}{lccc}
\hline Parameter & $\begin{array}{c}\text { Hypertensives } \\
\mathbf{n}=\mathbf{1 4 0}\end{array}$ & $\begin{array}{c}\text { Controls } \\
\mathbf{n = 7 0}\end{array}$ & $\boldsymbol{P}$ value \\
\hline Age (years) & $55.14 \pm 10.83$ & $54.67 \pm 10.89$ & 0.792 \\
Female, $\mathrm{n}(\%)$ & $75(53.6)$ & $37(52.9)$ & 0.672 \\
Mean WC, Male (cm) & $92.5 \pm 13.4$ & $84.0 \pm 7.3$ & $0.000^{\star}$ \\
Mean WC, Female (cm) & $94.3 \pm 11.5$ & $84.6 \pm 10.7$ & $0.000^{\star}$ \\
Mean HC (cm) & $100.15 \pm 11.63$ & $92.79 \pm 9.92$ & $0.015^{\star}$ \\
Mean WHR & $0.94 \pm 0.082$ & $0.91 \pm 0.054$ & 0.053 \\
Mean BMI (kg/m2) & $26.89 \pm 5.31$ & $23.86 \pm 3.46$ & $0.0045^{\star}$ \\
\hline
\end{tabular}

* Statistically significant. WC=waist circumference; $\mathrm{HC}=$ Hip circumference; WHR=waist hip ratio; BMI=Body mass index

overview of the frequency of metabolic syndrome in a population. The aim of this study was to compare the frequency of occurrence of metabolic syndrome using three standard international criteria/definitions and to study the distribution of cardiovascular risk factors among newly diagnosed hypertensive Nigerians.

\section{Materials and Methods}

This study was carried out in the Department of Medicine of Ladoke Akintola University of Technology Teaching Hospital (LAUTECH), Osogbo, Nigeria. Institutional ethical approval was obtained for the study from the LAUTECH Teaching Hospital research and ethical board. It was a cross-sectional study consisting of 140 consecutive newly diagnosed hypertensive subjects and 70 normotensive controls. The controls were hospital staff, patients' relatives, and students who voluntarily gave their consent to participate. The control subjects were age- and sex-matched with the hypertensive subjects. The diagnosis of hypertension was made according to standardized criteria ${ }^{18}$ (subjects with systolic blood pressure of $\geq 140 \mathrm{mmHg}$ and/or diastolic blood pressure $\geq 90 \mathrm{mmHg}$ taken twice after at least five minutes of rest in the clinic). Subjects with mild hypertension defined by the Joint National Committee Report VII ( JNC7 Stage 1) were asked to return after two weeks for further review and confirmation. Those with moderate and severe hypertension (JNC7 Stage 2) were recruited for the study immediately. Exclusion criteria included evidence of chronic renal impairment, pregnancy, current illnesses, and those with previously diagnosed diabetes mellitus. Subjects' socio-demographic data, clinical history, examinations, and investigations were taken.

Waist circumference (in centimeters) was measured at the mid-point between the lowermost rib and the iliac crest on expiration. The hip circumference (in centimeters) was taken across the greater trochanters. The waist-to-hip ratio (WHR) was determined. Blood samples were collected after at least eight hours overnight fast for serum biochemistry, lipid profile (including total cholesterol [TC], low-density lipoprotein cholesterol [LDL-C], high-density lipoprotein cholesterol [HDL-C] and triglycerides [TG]), and plasma glucose in all participants. Laboratory analysis of fasting serum lipids was performed using the Randox laboratories lipid profile kit (United Kingdom). Hypertriglyceridemia was defined as serum triglycerides $>1.7 \mathrm{mmol} / \mathrm{L}$, hypercholesterolemia as serum cholesterol $>6.5 \mathrm{mmol} / \mathrm{L}$, reduced HDL as serum HDL $<1.30 \mathrm{mmol} / \mathrm{L}$ (females) and $<1.03 \mathrm{mmol} / \mathrm{L}$ (males). Fasting plasma glucose was done by the glucose oxidase method.

Statistical analysis was performed using Statistical Package for Social Sciences (SPSS) software (version 16, SPSS, Inc, Chicago, IL, USA). Continuous and categorical variables were displayed as means \pm standard deviation (SD) and percentages, respectively. The student's $t$-test was used to assess the differences between means. Differences between

Table 3. Distribution of other cardiovascular risk factors and frequency of occurrence of metabolic syndrome in the study population.

\begin{tabular}{lccc}
\hline Parameter & $\begin{array}{c}\text { Hypertensives } \\
\mathbf{n = 1 4 0}\end{array}$ & $\begin{array}{c}\text { Controls } \\
\mathbf{n = 7 0}\end{array}$ & $\boldsymbol{P}$ value \\
\hline WC $>102 \mathrm{~cm}$ (males) & $16(24.6 \%)$ & $1(3.0 \%)$ & $<0.05^{\star}$ \\
WC $>88 \mathrm{~cm}$ (females) & $48(64.0 \%)$ & $12(32.4 \%)$ & $<0.05^{\star}$ \\
HDL-C $<1.03 \mathrm{mmol} / \mathrm{L}$ (males) & $25(38.5 \%)$ & $9(27.3 \%)$ & $<0.05^{*}$ \\
HDL-C $<1.30 \mathrm{mmol} / \mathrm{L}$ (females) & $42(56.0 \%)$ & $20(54.1 \%)$ & $<0.05^{\star}$ \\
TG $>1.7 \mathrm{mmol} / \mathrm{L}$ & $21(15.0 \%)$ & $7(10 \%)$ & $<0.05^{\star}$ \\
FPG $>6.1 \mathrm{mmol} / \mathrm{L}$ & $29(20.7 \%)$ & $2(2.9 \%)$ & $<0.05^{\star}$ \\
FPG $>5.6 \mathrm{mmol} / \mathrm{L}$ & $60(42.9 \%)$ & $7(10.0 \%)$ & $<0.05^{\star}$ \\
WC $>94 \mathrm{~cm}$ (Males) & $32(49.2 \%)$ & $3(9.1 \%)$ & $<0.05^{\star}$ \\
WC $>80 \mathrm{~cm}$ (females) & $64(85.3 \%)$ & $20(54.1 \%)$ & $<0.05^{\star}$ \\
WHR $>0.9$ (Males) & $46(70.8 \%)$ & $13(39.4 \%)$ & $<0.05^{\star}$ \\
WHR $>0.85$ (females) & $45(60.0 \%)$ & $19(51.4 \%)$ & $<0.05^{\star}$ \\
\hline
\end{tabular}

* Statistically significant. WC=Waist circumference; HDL-C=High density lipoprotein cholesterol; TG=Triglycerides; FPG-Fasting plasma glucose; WHR=waist-hip ratio.

$28 \quad$ Metabolic syndrome in hypertensives 
Table 4. Prevalence of metabolic syndrome among hypertensives according to three standard definitions/criteria.

\begin{tabular}{|c|c|c|c|}
\hline Criteria & $\begin{array}{c}\text { Male } \\
(n=65)\end{array}$ & $\begin{array}{l}\text { Female } \\
(n=75)\end{array}$ & Total \\
\hline ATP III & $\begin{array}{c}20 \\
(30.8 \%, \mathrm{Cl} 19.6-42.0 \%)\end{array}$ & $\begin{array}{c}28 \\
(37.3 \%, \mathrm{Cl} 26.6-48.0 \%)\end{array}$ & $\begin{array}{c}48 \\
(34.3 \%, \mathrm{Cl} 26.4-42.2 \%)\end{array}$ \\
\hline WHO & $(33.8 \%, \mathrm{Cl} 22.31-46.3 \%)$ & $\begin{array}{c}27 \\
(36.0 \%, \mathrm{Cl} 25.2-46.8 \%)\end{array}$ & $\begin{array}{c}49 \\
(35.0 \%, \mathrm{Cl} 27.1-42.9 \%)\end{array}$ \\
\hline IDF & $\begin{array}{c}23 \\
(35.4 \%, \mathrm{Cl} 23.8-47.0 \%)\end{array}$ & $\begin{array}{c}37 \\
(49.3 \%, \mathrm{Cl} 38.1-60.5 \%)\end{array}$ & $\begin{array}{c}60 \\
(42.9 \%, \text { Cl 34.7-51.1\%) }\end{array}$ \\
\hline
\end{tabular}

categorical variables were analyzed by chi-square test and the analysis of variance (ANOVA) for continuous variables. $P$ values $<0.05$ were considered to be statistically significant.

\section{Results}

Hypertensive subjects and normal controls were matched well in age and gender distribution. Hypertensive subjects had a higher mean waist circumference $(94.3 \pm 11.5 \mathrm{~cm}$ [females]) than normotensive controls (84.6 $\pm 10.7 \mathrm{~cm}$ [females]), respectively. Body mass index (BMI) and hip circumference were significantly higher among hypertensive subjects than normal controls as shown in table 2 .

Table 3 shows the pattern of distribution of major cardiovascular risk factors among the study population. Hypertensive subjects had a higher prevalence of all cardiovascular risk factors. Visceral obesity was the most prevalent of the other cardiovascular risk factors using the IDF population-based classification, followed by low-HDL and impaired fasting glucose in the study population.

Table 4 shows the prevalence of metabolic syndrome based on the three standard definitions. The ATP III and the WHO definitions gave similar prevalence $(34.3 \%$ vs. $35 \%$, respectively), while the IDF definition gave a higher prevalence of $42.9 \%$.

Table 5 shows the comparison of clinical and laboratory characteristics between male and female hypertensive subjects.
Female hypertensive subjects had a higher mean waist circumference $(103.7 \pm 11.52 \mathrm{~cm}$ vs. $93.4 \pm 12.4 \mathrm{~cm}, P<0.05)$ and BMI (27.7 \pm 5.7 vs. $\left.25.7 \pm 4.5 \mathrm{~kg} / \mathrm{m}^{2}, P<0.05\right)$ respectively, compared to their male counterparts. Female subjects had a higher systolic blood pressure (148.4 \pm 24.2 vs. $142.4 \pm 29.8$ $\mathrm{mmHg}, P>0.05)$, and pulse pressure (59.7 \pm 18.2 vs. $53.6 \pm 30.4$ $\mathrm{mmHg}, P>0.05)$ than their male counterparts, respectively; however, these were not statistically significant.

\section{Discussion}

This study demonstrated that the prevalence of metabolic syndrome among newly diagnosed, non-diabetic, hypertensive Nigerian subjects was similarly high using the WHO and the NCEP ATP III criteria. The IDF criteria, however, resulted in a higher prevalence. This was because of the lower cut-off value for waist circumference required to diagnose visceral obesity that is population-specific according to the IDF criteria. Using any of the three criteria, at least one third of newly diagnosed, non-diabetic, hypertensive subjects were diagnosed with metabolic syndrome in this study. The three definitions have been shown to identify individuals who have metabolic syndrome and are at an increased risk for cardiovascular diseases. This study agrees with other reports that have shown that the prevalence of metabolic syndrome is similar among a particular group using these various criteria/ definitions. ${ }^{19-21}$

The prevalence of metabolic syndrome among hypertensive subjects in this study was between $34.3 \%$ and $42.9 \%$,

Table 5. Clinical and laboratory characteristics of male and female hypertensive subjects.

\begin{tabular}{lccc}
\hline Variable (mean) & $\begin{array}{c}\text { Male } \\
(\mathbf{n = 6 5 )}\end{array}$ & $\begin{array}{c}\text { Female } \\
(\mathbf{n}=\mathbf{7 5})\end{array}$ & $\boldsymbol{P}$ value \\
\hline Age (years) & $54.9 \pm 11.5$ & $54.5 \pm 10.7$ & 0.862 \\
SBP (mmHg) & $142.4 \pm 29.8$ & $148.4 \pm 24.2$ & 0.191 \\
DBP (mmHg) & $88.8 \pm 17.7$ & $88.7 \pm 16.5$ & 0.828 \\
WC (cm) & $93.4 \pm 12.4$ & $103.7 \pm 11.52$ & $0.013^{\star}$ \\
FBS (mmol/L) & $5.7 \pm 2.3$ & $5.3 \pm 1.6$ & 0.105 \\
TG (mmol/L) & $1.2 \pm 0.4$ & $1.2 \pm 0.5$ & 0.648 \\
TC (mmol/L) & $4.7 \pm 1.53$ & $4.4 \pm 1.2$ & 0.216 \\
HDL (mmol/L) & $1.2 \pm 0.43$ & $1.2 \pm 0.48$ & 0.383 \\
BMI (kg/m $\left.{ }^{2}\right)$ & $25.7 \pm 4.5$ & $27.7 \pm 5.7$ & $0.007^{\star}$ \\
PP (mmol/L) & $53.6 \pm 30.4$ & $59.7 \pm 18.2$ & 0.116 \\
\hline
\end{tabular}

* Statistically significant. SBP=Systolic blood pressure; DBP=Diastolic blood pressure; WC=waist circumference; FBS=Fasting blood sugar; TG=triglycerides; $\mathrm{TC}=$ Total cholesterol; HDL=High density lipoprotein; $\mathrm{BMI}=$ Body mass index; PP=Pulse pressure. 
depending on the criteria used. This is similar to what was reported among newly diagnosed South African hypertensive subjects. ${ }^{22}$ It is, however, lower compared to values reported from developed countries like the United States and many European countries. ${ }^{23,24}$ Farsang et $\mathrm{al}^{23}$ reported that the prevalence of metabolic syndrome in hypertensive subjects across Europe varies between $50 \%$ to $68 \%$, with the highest reported from Central Europe and the lowest reported from the Mediterranean. This inter-regional difference has been suggested to be due to nutritional factors, exercise, and genetics. In a report from Spain, $52 \%$ of a hypertensive cohort fulfilled the criteria for the diagnosis of metabolic syndrome. ${ }^{25}$ The variation observed in prevalence is likely due to the interplay of many factors such as impact of genetics/race, lifestyle, and prevalence of the constituent cardiovascular risk factors. ${ }^{1,26}$ Dyslipidemia has been reported to be lower among Black Africans than Caucasians. ${ }^{27}$ The prevalence rate of obesity continues to increase worldwide which may lead to an increase in the prevalence rate of metabolic syndrome unless aggressive primary and secondary prevention strategies are implemented. The reported lower frequency of occurrence of metabolic syndrome among our study participants compared to Caucasians is suggested to be due to racial factors and possibly a lower prevalence of obesity and dyslipidemia among native Black Africans.

Obesity was the most common of the other cardiovascular risk factors present among hypertensive and normotensive patients. Obesity has been suggested as the major underlying risk factor driving the presence of metabolic syndrome. There were more females than males with metabolic syndrome, although this was not statistically significant. This was due to higher a proportion of obesity among females. Visceral obesity engenders insulin resistance that can precipitate dyslipidemia and other components of metabolic syndrome. This may be deduced because clinical and demographic characteristics are similar among male and female hypertensives, except in terms of indicators of obesity both in terms of waist circumference and BMI. Therefore, the higher prevalence of metabolic syndrome among females is likely to be significantly related to the differential prevalence of obesity between the male and female hypertensive subjects.

However, it should be a serious public health concern that at least a third of newly diagnosed hypertensive patients can be diagnosed as having the cardiometabolic syndrome. This places them already at increased risk for cardiovascular disease and events. The WHO predicts that the prevalence of cardiovascular disease worldwide will double by the year 2020, and most of the increase will come from the developing countries. ${ }^{5}$ Therefore, efforts should be initiated toward appropriate public health interventions and early identification of individuals at risk of cardiovascular disease. There is, therefore, the need to adequately screen newly diagnosed hypertensive patients for other cardiovascular risk factors and to institute appropriate strategies for the control of obesity in order to achieve improved cardiovascular care and reduce the burden of cardiovascular diseases among them. Furthermore, identification of multiple cardiovascular risk factors among obese individuals, those with hyperlipidemia, and those with a family history of cardiovascular disease as a populationbased health intervention strategy will improve cardiovascular care and ultimately reduce the cardiovascular risk burden among the population at large.

\section{Conclusion}

Clustering of cardiovascular risk factors was common among newly diagnosed hypertensive subjects. The WHO and NCEP ATP III definitions resulted in similar prevalence of metabolic syndrome. However, the IDF criteria resulted in a higher prevalence due to the race-specific definition of visceral obesity.

\section{References}

1. Cornier MA, Dabelea D, Hernandez TL, Lindstrom RC, Steig AJ, Stob NR, Van Pelt RE, Wang H, Eckel RH. The metabolic syndrome. Endoc Rev 2008;29:777-822.

2. Miranda PJ, Defronzo RA, Califf RM, Guyton JR. Metabolic syndrome: definition, pathophysiology, and mechanisms. Am Heart J 2005; 149:33-45.

3. The World Health Report 2002: Reducing risks, promoting healthy life. World Health Organization. Geneva, Switzerland. Available at: http://www.who.int/whr/2002/en/. Accessed May 2, 2005.

4. Cooper R, Rotimi C, Ataman S, McGee D, Osotimehin B, Kadiri S, Muna W, Kingue S, Fraser H, Forrester T, Bennett F, Wilks $\mathrm{R}$. The prevalence of hypertension in seven populations of West African origin. Am J Public Health 1997;87:160-168.

5. Yusuf S, Reddy S, Ounpuu S, Anand S. Global burden of cardiovascular disease: Part I: general considerations, the epidemiologic transition, risk factor and impact of urbanization. Circulation 2001;104:2746-2753

6. Grundy SM, Hansen B, Smith SC Jr.,Cleeman JI, Kahn RA; American Heart Association; National Heart, Lung and Blood Institute; American Diabetes Association. Clinical management of metabolic syndrome: report of the American Heart Association/National Heart, Lung and Blood Institute/ American Diabetes Association conference on scientific issues related to management. Arterioscler Thromb Vasc Biol 2004;24:e19-e24.

7. Reaven GM. Banting lecture 1988. Role of insulin resistance in human disease. Diabetes 1988;37:1595-1600.

8. Isezuo SA, Badung SL, Omotoso AB. Comparative analyses of lipid profiles among patients with type 2 diabetes mellitus, hypertension and concurrent type 2 diabetes, and hypertension: a view of metabolic syndrome. J Nat Med Assoc 2003;95:328-334.

9. Obasohan AO, Ajuyah CO. How common is heart failure due to hypertension alone in hospitalised Nigerians? J Human Hypertens 1996;10:801-804.

10. Lakka HM, Laaksonen DE, Lakka TA, Niskanen LK, Kumpusalo E, Tuomilehto J, Salonen JT. The metabolic syndrome and total and cardiovascular disease mortality in middle-aged men. JAMA 2002;288:2709-2716.

11. Alberti KG, Zimmet PZ. Definition, diagnosis and classification of diabetes mellitus and its complications. Part I: diagnosis and classification of diabetes mellitus provisional report of a WHO consultation. Diabet Med 1998; 15:539-553. 
12. Expert Panel on Detection, Evaluation, and Treatment of High Blood Cholesterol in Adults. Executive summary of the third report of the National Cholesterol Education Program (NCEP) Expert Panel on detection, evaluation, and treatment of high blood cholesterol in adults (Adult Treatment Panel III). JAMA 2001;285:2486-2497.

13. Alberti KG, Zimmet P, Shaw J. Metabolic syndrome-a new world-wide definition. A consensus statement from the International Diabetes Federation. Diabet Med 2006; 23:469-480.

14. Kahn R, Buse J, Ferrannini E,Stern M; American Diabetes Association; European Association for the study of Diabetes. The metabolic syndrome: time for a critical appraisal: joint statement from the American Diabetes Association and the European Association for the Study of Diabetes. Diabetes Care 2005;28:2289-2304.

15. Bonora E. The metabolic syndrome and cardiovascular disease. Ann Med 2006;38:64-80.

16. Reaven GM. The role of insulin resistance in human disease. Diabetes 1988; 37:1595-1607.

17. Wilson PW, D'Agostino RB, Parise H, Sullivan L, Meigs JB. Metabolic syndrome as a precursor of cardiovascular disease and type 2 diabetes mellitus. Circulation 2005; 112:3066-3072.

18. Chobanian AV, Bakris GL, Black HR,Cushman WC, Green LA, Izzo JL, Jones DW, Materson BJ, Oparil S, Wright JT Jr, Roccella EJ, Joint National Committee on Prevention, Detection, Evaluation, and Treatment of High Blood Pressure. National Heart, Lung, and Blood Institute; National High Blood Pressure Education Program Coordinating Seventh report of the Joint National Committee on Prevention, Detection, Evaluation, and Treatment of High Blood Pressure. Hypertension 2003;42:1206-1252.

19. Assmann G, Guerra R, Fox G, Cullen P, Schulte H, Willett D, Grundy SM. Harmonizing the definition of the metabolic syndrome: comparison of the criteria of the Adult Treatment Panel II and the International Diabetes Federation in United States American and European populations. Am J Cardiol 2007;99:668-672.

20. Cameron AJ, Magliano DJ, Zimmet PZ, Welborn T, Shaw JE. The metabolic syndrome in Australia: prevalence using four different definitions. Diabetes Res Clin Pract 2007; 77:471-478.

21. Sandhofer A, Iglseder B, Paulweber B, Ebenbichler CF, Patsch JR. Comparison of different definitions of the metabolic syndrome. Eur J Clin Invest 2007;37:109-116.

22. Okpechi IG, Pascoe MD, Swanepoel CR, Rayner BL. Microalbuminuria and the metabolic syndrome in nondiabetic black Africans. Diab Vasc Dis Res 2007;4:365-367.

23. Farsang C, Naditah-Bruce L,Perlini S, Zidek W, Kjeldoen SE: GOOD investigators. Inter- regional comparisons of the prevalence of cardiometabolic risk factors in patients with hypertension in Europe: The GOOD survey. J Hum Hypertens 2009;23:316-324.

24. Ford ES, Giles WH, Dietz WH. Prevalence of the metabolic syndrome among US adults: findings from the third National Health and Nutrition Examination Survey. JAMA 2002;287:356-359.

25. Barrios V, Escobar C, Calderón A, Llisterri JL, Alegría E, Muñiz J, Matalí A. Prevalence of the metabolic syndrome in patients with hypertension treated in general practice in Spain: an assessment of blood pressure and low-density lipoprotein cholesterol control and accuracy of diagnosis. J Cardiometab Syndr 2007;2:9-15.

26. Prussian KH, Barksdale-Brown DJ, Dieckmann J. Racial and ethnic differences in the presentation of metabolic syndrome. J Nurse Pract 2007;3:229-239.
27. Kesteloot H, Oviasu VO, Obasohan AO, Olomu A, Cobbaert C, Lissens W. Serum lipid and apolipoprotein levels in a

Nigerian population sample. Atherosclerosis 1989;78:33-38.

\section{Author Affiliations}

Adeseye A. Akintunde, $M B C h B, F W A C P^{*}+$;

Olugbenga E. Ayodele, MBBS, FWACP*;

Patience O. Akinwusi, MBChB, FWACP*;

George O. Opadijo, MBBS, FWACP*

${ }^{*}$ Division of Cardiology, Ladoke Akintola University of Technology Teaching Hospital, Osogbo, Nigeria

†Cardiology Clinic, Eberhards Karls University, Tubingen, Germany 